\title{
Effects of ruminant digestion on germination of Lehmann love-grass seed
}

\author{
E.L. FREDRICKSON, R.E. ESTELL, K.M. HAVSTAD, T. KSIKSI, J. VAN TOL, AND M.D. REMMENGA
}

Authors are, respectively, research scientists, research leader, research technicians, USDA-ARS, Jornada Experimental Range, Box 30003, Dept. 3JER, NMSU, Las Cruces, N.M. 88003-0003 and statistician, New Mexico State University, Las Cruces. Ksiksi is currently a doctoral student in Range and Wildlife Sciences, Texas Tech University, Lubbock, Tex.

Abstract

Lehmann lovegrass (Eragrostis lehmanniana Nees) seed (germination $96 \%$, dormant $0 \%$ ) was used in 4 experiments to study the potential of sheep as a dispersal agent. Five, 4-year-old, ruminally cannulated wethers were used to examine effects of ruminant digestion on seed recovery and germination. All wethers were ruminally evacuated, and rumens were cleansed and reinoculated with strained ruminal fluid. After a 21-day adaptation to pelleted alfalfa, 4 experiments were conducted. Experiment 1 was designed to test viability of Lehmann lovegrass seeds exposed to ruminal and postruminal digestion. Lehmann lovegrass seed (10 $\mathrm{g}$ ) was dosed intra-ruminally via ruminal fistula, and total fecal collections made. Of the viable seed ruminally dosed, $37 \%$ germinated within 21 days after recovery. Also, 98 to $100 \%$ of the seed that germinated was recovered within 72 hours of dosing. Experiment 2 was designed to test the influence of ruminal microbial digestion on seed degradation and viability, using in sacco nylon bag techniques. In sacco dry matter disappearance increased linearly from $5.5 \%$ at 3 hours of incubation to $16 \%$ at 120 hours. Germination of seed was not greatly affected until after 72 hours of ruminal incubation. Experiment 3 was designed to examine the effect of mastication on viability of Lehmann lovegrass seeds. Seeds were mixed with seed-free Lehmann lovegrass straw in a proportion of 1 to 10 (seed to straw) and $10 \mathrm{~g}$ fed to each wether. Boli were recovered manually via ruminal fistula. Thirty five percent of the seed fed entered the rumen without damage due to mastication. Experiment 4 compared in vitro techniques and in sacco techniques used to estimate the effect of digestion on seed viability. In vitro incubation techniques yielded similar results as in sacco techniques. We conclude that ruminants are potential disseminating agents of Lehmann lovegrass seed.

Key Words: Eragrostis lehmanniana, seed dispersal, digestion, mastication, sheep.

In 1932, several South African grasses were imported to the southwestern United States to reclaim land damaged by a combi-

\footnotetext{
The authors wish to acknowledge the assistance of an anonymous person for providing animal care while animals were housed at USDA-ARS Sheep Research Facilities operated in cooperation with La Tuna Federal Correctional Facilities. We also acknowledge the technical assistance of Richard Kochavar, Director, New Mexico Department of Agriculture's Seed Testing Laboratory.

Manuscript accepted 9 Mar. 1996
}

Resúmen

Semillas de pasto Africano (Eragrostis lehmanniana) con una germinación de $96 \%$, fueron utilizadas en 4 experimentos para estudiar el potencial de los ovinos como agentes dispersantes de semilla. Se utilizaron 5 carneros con fistula ruminal para examinar los efectos de la digestion ruminal sobre la recuperación y germinación de la semilla. Después de un periodo de adaptación de 21 dias, se iniciaron los experimentos: Experimento 1.- Se dosificaron $10 \mathrm{~g}$ de semilla intraruminalmente, colectando todas las heces fecales. A las 72 horas se recupero el $90 \%$ de la semilla y a los 21 dias, germino el $37 \%$ de esta. Experimento 2.Utilizando bolsas de nylon in sacco, se probo la influencia de la digestión ruminal sobre la degradación y viabilidad de la semilla. La desaparición de la materia seca se incremento linearmente de $5.5 \%$ a 3 horas de incubacion, a $16 \%$ a las 120 horas. La germinación de la semilla no fue afectada hasta después de 72 horas de incubacion ruminal. Experimento 3.- Se busca examinar el efecto de la masticación sobre la viabilidad de las semillas. Las semillas fueron mezcladas con paja en una proporción 1 a 10 . EI bolo ruminal fue recuperado manualmente a través de la fistula ruminal y el 35\% de la semilla no fue dañado por la masticación. Experimento 4.- Se comparo la digestibilidad in vitro con la digestibilidad in sacco en términos de la viabilidad de la semilla, más no fueron detectadas diferencias. Con estos experimentos, se concluye que los rumiantes son agentes diseminadores potenciales de semillas de past Africano.

nation of overuse and drought (Cox et al. 1988). Among these grasses, Lehmann lovegrass (Eragrostis lehmanniana Nees) establishes easily, and flourishes in areas too harsh for many revegetation species. Within 8 years of introduction, this species was used in revegetation projects throughout southwest Texas, southern New Mexico and southern Arizona. Although this species lessens soil erosion and provides good early season forage, it is also a highly competitive plant that is less palatable than native species (Ruyle and Cox 1985). Replacement of more palatable and nutritious native grass species has resulted in pure stands of Lehmann lovegrass (Anable et al. 1992). The area of expansion now exceeds the area of introduction (Cox and Ruyle 1986). Furthermore, expansion of Lehmann lovegrass may escalate due to development and release of cold hardy hybrids (Holzworth 1980).

Currently, expansion of Lehmann lovegrass is attributed to caryopsis (hereafter referred to as seed) dispersal by wind and surface water movement. Anable et al. (1992) examined the 
spread of Lehmann lovegrass into livestock exclosures and concluded that livestock are not necessary for seed dispersal. Yet, ruminants apparently act as dispersal agents of some grasses (Janzen 1984) and livestock may be involved in Lehmann lovegrass expansion. The objectives of our research were to 1) examine the influence of mastication and ruminal total tract digestion by sheep on passage rate, recovery and germination of Lehmann lovegrass seed and 2) compare in vitro and in sacco techniques to evaluate effects of ruminant digestion on seed germination.

\section{Materials and Methods}

Lehmann lovegrass seed purchased for these experiments was stated by the vendor to contain $99.41 \%$ pure seed with a germination of $40 \%$ plus $45 \%$ dormant seed (Lot No. 14117, Granite Seed Company, Lehi, Utah). A sample of the seed was submitted to New Mexico Department of Agriculture State Seed Laboratory, Las Cruces, N.M. to verify species and purity, plus germination and dormancy percentages. Germination and dormancy estimates obtained from the State Seed Laboratory were then used to verify our estimates of germination and dormancy percentages. For experiments requiring estimates of germinable seed (seed germinating within 21 days under standard conditions), 100 seeds were placed on $9 \mathrm{~cm}$ no. 615 qualitative filter paper ${ }^{1}$ in $10 \times 1.5 \mathrm{~cm}$ Petri dishes containing seed germination paper ${ }^{2}$. After wetting the seeds with a $0.2 \% \mathrm{KNO}_{3}$ solution containing captan, labeled Petri dishes were then placed in sandwich bags, sealed and incubated in a growth chamber with a 16 hour dark period at $20^{\circ} \mathrm{C}$ followed by 8 hours light at $30^{\circ} \mathrm{C}$. Seedlings were counted and removed every 7 days until 21 days when both seedlings and unsprouted seed were counted. When indicated, presence of viable dormant seed was cstimated using a topographical tetrazolium test (2, 3, 5-triphenyl tetrazolium; AOSA 1970). To determine the number of seeds per gram of air equilibrated dry weight, 23 , one gram samples were manually counted. From these counts we determined that 13,309 seeds $( \pm 169)$ weigh $1 \mathrm{~g}$.

Five, 4-year-old, ruminally cannulated Polypay $\times$ Rambouillet wethers were housed in individual pens $(1.5 \times 6 \mathrm{~m})$ with free access to fresh water. Salt supplements were not offered during the study. Before initiation of the study, ruminal contents were evacuated manually and the rumen was cleansed until water removed from the rumen was clear and without particulate matter to remove seeds from other plant species. An aliquot $(300 \mathrm{ml})$ of ruminal fluid was strained through 8 layers of cheesecloth and reintroduced into the rumen as a source of inoculum. During the next 21 days, all wethers were fed 2 equal proportions of prebloom pelleted alfalfa at 0800 and 1600 hours to provide $35 \mathrm{~g}$ dry matter $\bullet \mathrm{kg}$ body weight ${ }^{-1} \cdot$ day $^{-1}$. Alfalfa was pelleted into $95 \mathrm{~mm}$ pellets after being ground to pass a $32 \mathrm{~mm}$ sieve. Alfalfa pellets were sampled weekly, composited, and submitted for wet lab analysis (DHIA Forage Testing Laboratory, Ithaca, N.Y.). Results of these analyses are listed in Table 1 . After the 21 day adaption period, wethers were used in the following 4 experiments.

\footnotetext{
Ahlstrom Flltration, Mt. Holly Springs, Penn.

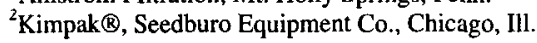

Table 1. Compositional analysis of alfalfa pellets

\begin{tabular}{lc}
\hline \hline Component & \\
\hline Dry matter, \% & 91.5 \\
& Dry matter basis \\
Crude protein, \% & 18.9 \\
Acid detergent fiber, \% & 26.1 \\
Neutral detergent fiber, \% & 33.1 \\
Calcium, \% & 1.82 \\
Phosphorus, \% & 0.21 \\
Magnesium, \% & 0.4 \\
Sodium, \% & 0.158 \\
Iron, ppm & 286 \\
Zinc, ppm & 25 \\
Manganese, ppm & 46 \\
Molybdenum, ppm & 4.8 \\
\hline
\end{tabular}

\section{Experiment 1}

This experiment examined germination of ruminally dosed Lehmann lovegrass subjected to both ruminal and postruminal digestion. The day prior to dosing Lehmann lovegrass seed, all wethers were fitted with total fecal collection bags. At 0700 hours the following day, fecal bags were emptied and $10 \mathrm{~g}(133,090$ seeds) of air-dried Lehmann lovegrass seed was placed into the rumen, cranial to the dorsal pillar and ventral to the ruminal cardia. For 10 days fecal bags were emptied daily at 0700 hours and feces thoroughly mixed and weighed. Five, $10 \mathrm{~g}$ aliquots of feces (wet basis) were placed on 40 and 60 mesh standardized soil sieves and cool tap water was run over the feces until feces were completely dissociated and particle size appeared uniform. Residual remaining on the sieves was then placed in Petri dishes and percent germination was determined. Sieve sizes were selected based on a preliminary study in which known amounts of seeds were added to $10 \mathrm{~g}$ of seed-free feces and seed recovery was measured and calculated. Recovery using this method was $96 \%$ ( $\mathrm{SE}=2.4$ ) for 20 replicates. Another aliquot of feces was obtained each day for dry matter (DM) and ash content (AOAC 1990).

Statistical analyses across days were performed using GLM procedures of SAS (1989). Data were arranged in a randomized complete block design with data blocked by wether and day used as treatment. Blocking by wether accounts for the correlation among days within wether. Log transformations (count +1 ) were made to normalize the data. In the case of a significant $(P<0.05)$ F-test, means were separated using Sheffe's mean separation procedures.

\section{Experiment 2}

This experiment estimated the influence of ruminal digestion on seed germination, and immediately followed Experiment 1. Preweighed nylon bags ${ }^{3}(10 \times 15 \mathrm{~cm} ; 40 \mu \mathrm{m}$ pore size $)$ containing $1 \mathrm{~g}$ Lehmann luvegrass seed were incubated in duplicate with a blank, intraruminally for $0,3,6,12,24,36,48,72,96$, and 120 hours in each of the 5 wethers. After removal, the bags were washed until water draining from the bag was clear. One hundred seeds were removed from each bag for germination tests, the

\footnotetext{
${ }^{3}$ Ankom, Fairport, N.Y.
} 
remainder of the seeds were left in the nylon bags and dried at $45^{\circ} \mathrm{C}$ for 48 hours. Before calculating disappearance from the nylon bags, a correction factor (avg wt of 100 seeds) was added to the weight of the nylon bag contents. In sacco dry matter disappearance rate of seeds was calculated using a model described by Mertens and Loften (1980). Statistical analyses were performed as in Experiment 1, except that data were distributed normally, therefore log transformations were not performed.

\section{Experiment 3}

This experiment was designed to estimate degree of Lehmann lovegrass seed damage due to mastication. Seed-free, hand cut Lehmann lovegrass (length $<2.5 \mathrm{~cm}$ ) was mixed with Lehmann lovegrass seed in a proportion of 10 to 1 (DM basis). Each ruminally-evacuated wether was fed 10 grams of the mixture. The resulting boli were manually recovered via the ruminal fistula as boli entered the ruminal cardia. Boli were composited by animal, free moisture allowed to drain, and damaged and undamaged seeds were manually separated using a dissecting microscope. Undamaged seeds were defined as seeds with intact seed coats and having typical seed size and shape. Once separated, damaged and undamaged seeds were then dried at $45^{\circ} \mathrm{C}$ for 48 hours, allowed to air equilibrate and weighed. Means and standard errors of the proportion of damaged seed and seed recovery are reported.

\section{Experiment 4}

This experiment was designed to examine use of in vitro 2stage digestion techniques to estimate the effect of ovine digestion on germination of Lehmann lovegrass seed. For the most part, modifications of Tilley and Terry (1963) as described by Ocumpaugh and Swakon (1993) were used in this study. In brief, 100 seeds were placed in $50 \mathrm{ml}$ centrifuge tubes containing 0.25 $\mathrm{g}$ of alfalfa pellets ground to pass a $1 \mathrm{~mm}$ screen. To this, $28 \mathrm{ml}$ of McDougall's solution prewarmed to $39^{\circ} \mathrm{C}$ was added. Subsequently, $7 \mathrm{ml}$ of rumen fluid was added, the tube flushed with $\mathrm{CO}_{2}$, agitated and incubated in a water bath maintained at $39^{\circ} \mathrm{C}$ for $0,24,48$, or 72 hours. Inoculum was obtained from each wether 4 hours post-feeding (1200) on the last day of Experiment 2 and composited. After incubation, each tube was centrifuged for $20 \mathrm{~min}$. at $2,000 \times \mathrm{g}$ and liquid decanted from the tube. Next, $35 \mathrm{ml}$ of acid-pepsin was added to each tube and incubated at $39^{\circ} \mathrm{C}$ for 7 hours. Seeds and remaining alfalfa were isolated and thoroughly rinsed by filtration. Seeds were then counted and germination determined. Four replicates were used per incubation time, and alfalfa laboratory standards, with blanks, were run simultaneously using 48 hour ruminal fluid - 48 hour acid pepsin incubation times to compare activity of ruminal inoculum with prior runs.

\section{Results}

The seed used in this study had a germination percentage of $96 \%$ and no dormant seed. Germination estimates did not differ when measured after a 14 day prechill at $5^{\circ} \mathrm{C}$. Estimates obtained from the New Mexico Department of Agriculture State Seed Laboratory were similar (95\% germination and $0 \%$ dormant without prechill, $94 \%$ germination and $1 \%$ dormant with prechill). However, our estimates differed from those provided by the sup- plier (40\% germination, $45 \%$ dormant). This difference is probably due to a 6 month interval between the supplier's tests and ours, during which time an after-ripening effect may have occurred that altered dormancy (pers. comm., Mark Pater, NRCS, Tucson Plant Materials Center).

\section{Experiment 1}

The 24 hour period following ruminal dosing, 17,870 to 33,563 germinable seeds were excreted (mean $=21,873, \mathrm{SE}=6,622$ ), accounting for 13 to $25 \%$ of the seed ruminally dosed. During the second day, 16,840 to 26,496 germinable seeds (mean $=21,135$, $\mathrm{SE}=4,292$ ) were excreted while, 451 to 4,319 germinable seeds were excreted during day 3 (mean $=1,811, \mathrm{SE}=1,466$ ). Within the first 3 days, 98 to $100 \%$ of all germinable seeds were excreted. On day 4, the number of germinable seeds ranged from 0 to 422 (mean $=186, \mathrm{SE}=184$ ). . No germinable seeds were detected on day 5 , while 42 and 40 germinable seeds were found in the feces of wethers 18 and 223, respectively, on day 6 . No germinable seeds were found in fecal collections on days 7 and 8 . The last day germinable seeds were detected in the feces was day 9 when 40 germinable seeds were excreted by wether 280 . Interestingly, no seeds were detected in the feces of this wether for the 5 days prior to day 9 . Total seed recovery (number of germinable seeds detected in the feces per number of germinable seeds dosed) varied between 32 and $49 \%$ (mean $=37, \mathrm{SE}=7$ ). Because of the difficulty of finding seeds in the feces that did not germinate within 21 days, and due to the low percentage of dormant seed dosed, we did not count dormant or non-viable seeds. Consequently, recovery data may be slightly conservative.

\section{Experiment 2}

Percent ruminal in sacco dry matter (DM) disappearance of Lehmann lovegrass seed is illustrated in Figure 1. The nonlinear model of Mertens and Loften (1980) did not provide a good fit of the data. However, using linear regression following the initial disappearance of $6.0 \%(\mathrm{SE}=1.4)$ within the first 3 hours, disappearance increased at a rate of $0.09 \%$ hour $^{-1} \hat{y} 0.0876 x+6.0909$, $R^{2}=0.88$ ). At 72 hours, the time at which $98 \%$ of the seeds have exited the digestive tract, in sacco DM disappearance of seed was $13.4 \%$ ( $\mathrm{SE}=0.58)$. Because the population of seeds in nylon bags may change with incubation time, no adjustment was made for germinable seed $(96 \%)$. Percent germination of ruminally incubated seed is illustrated in Figure 2. Germination declined from $92.3 \%(\mathrm{SE}=0.92)$ at 0 hour to $76.1 \%(\mathrm{SE}=5.93)$ at hour 9. Percent germination did not change substantially until hour 96 (mean $=29.6, \mathrm{SE}=14.85)$; after which, percent germination declined to $2.1 \%(\mathrm{SE}=3.40)$ at hour 120 .

\section{Experiment 3}

Thirty-five percent of seed ( $S E=6$ ) fed did not appear to be damaged by mastication. Recovery of viable seeds fed in this experiment was $74 \%(S E=13)$. Incomplete recovery represents a potential source of bias.

\section{Experiment 4}

Using in vitro techniques percent of seeds germinating was 95 $(\mathrm{SE}=1.1), 89(\mathrm{SE}=5.5), 56(\mathrm{SE}=8.9)$, and $52(\mathrm{SE}=13.6)$ for incubation times of $0,24,48$, and 72 hours, respectively. Except for the loss of 4 seeds from 3 tubes incubated for 72 hours, and 2 seeds from 1 tube incubated for 48 hours, all seeds were recov- 


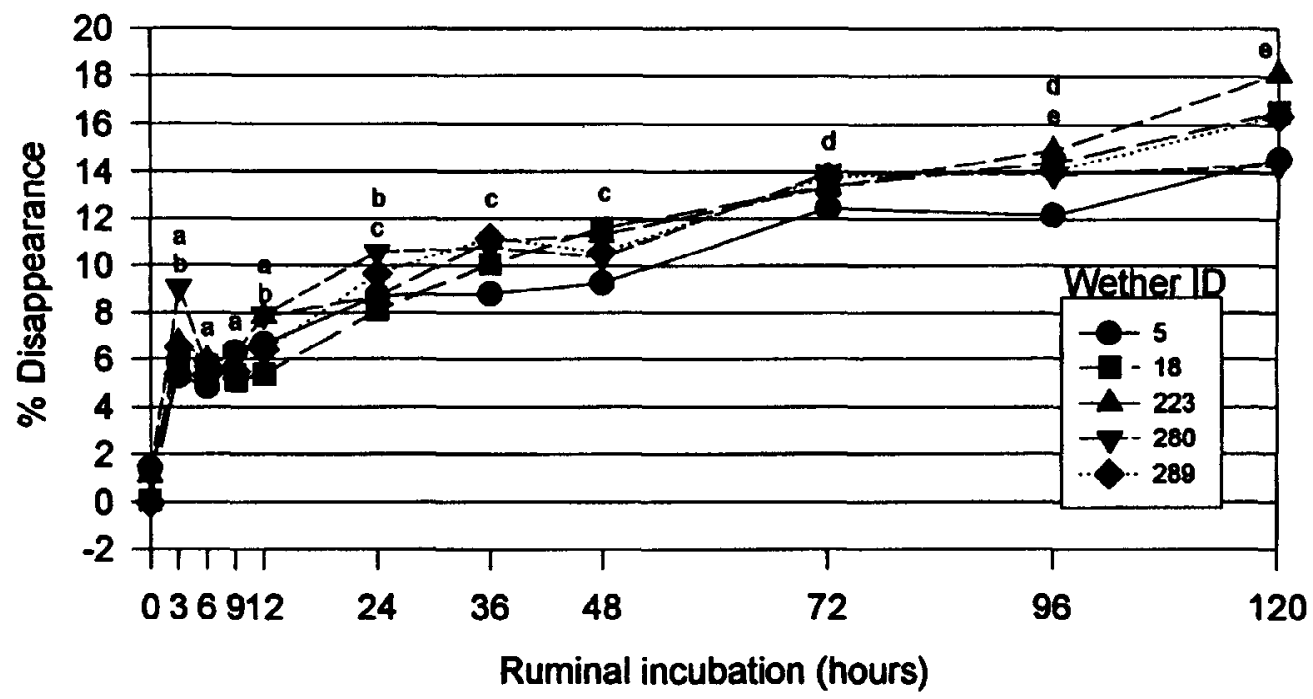

Fig. 1. In sacco dry matter disappearance of Lehmann lovegrass seed ruminally incubated in wethers. Hours with different letters differ, $P<0.05$.

ered. Because of the large standard error associated with these estimates, we determined viability of seeds that did not germinate. Of the seeds incubated for 48 and 72 hours, 10 (SE = 7.1) and $28 \%(\mathrm{SE}=11.0)$, respectively, of the seeds were viable but did not germinate within 21 days.

\section{Discussion}

A large proportion of Lehmann lovegrass seeds consumed by sheep remain viable after excretion. If seeds deposited on the soil via sheep feces germinate and become established, then established plants will form new loci from which dispersal of seeds by other mechanisms will increase plant density and encroachment into adjacent areas (Moody and Mack 1988). Because Lehmann lovegrass is a prolific seed producer, the probability of a seed becoming established can be very low, yet the probability of a plant becoming established may be quite high. The distance from the parent plant that a seed is deposited will be determined by interactions of animal behavior, physiology, and environmental constraints influencing animal travel, digestion, and dunging patterns. Germination and establishment of the seed, once deposited on the soil, depends upon a complex set of seed physiology by environmental interactions.

Livestock must first select and consume seeds to effectively distribute seed via digestive processes. After flowering, sheep and beef cattle often graze the tops of reproductive culms by stripping seed from the culm. This behavior often occurs between grazing bouts, and during the cessation of morning and afternoon feeding bouts when grazing intensity, as determined by bite rate,

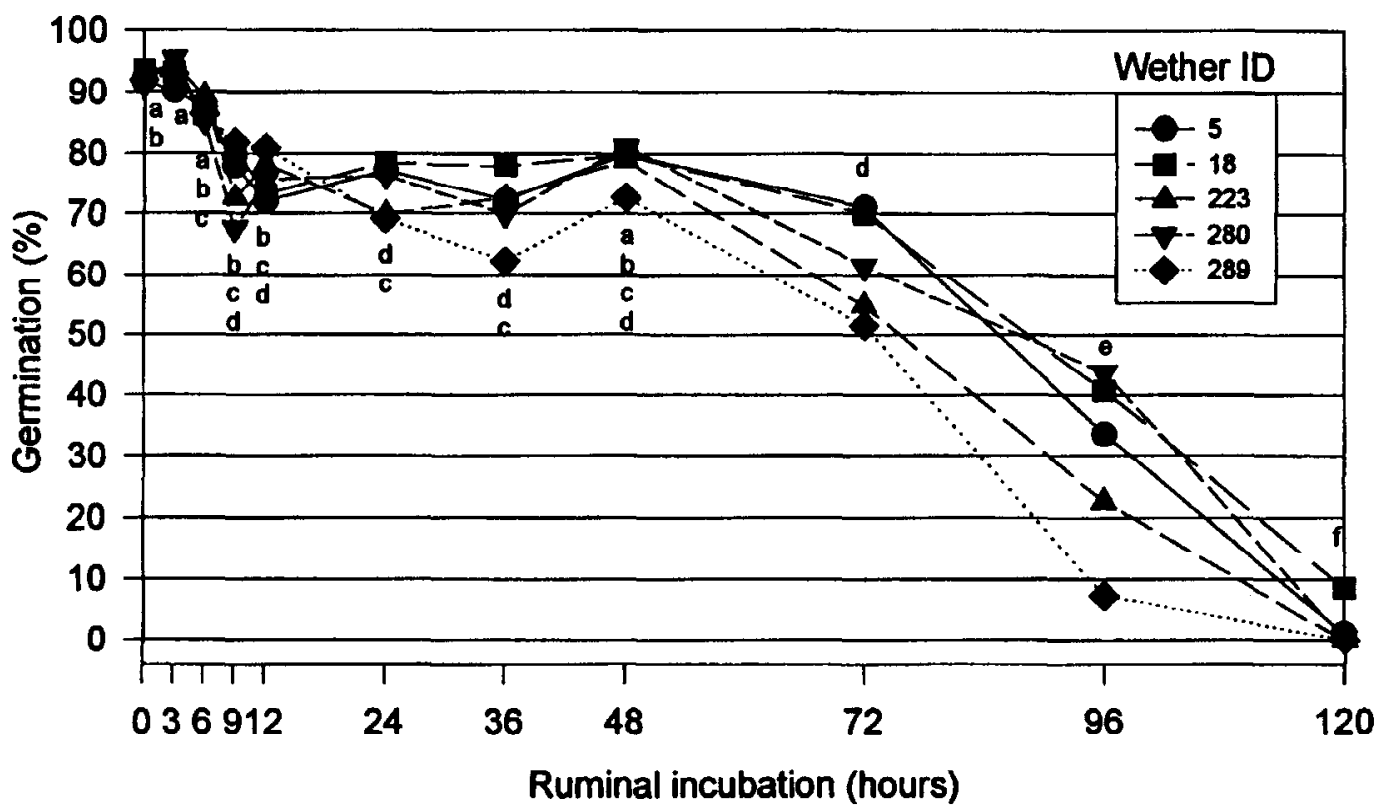

Fig. 2. Percent germination of Lehmann lovegrass seed ruminally incubated in wethers. Hours with different letters differ, $P<0.05$. 
is reduced. For example, Abu-Zanat (1989) observed that beef cows ate the top portions of Lehmann lovegrass to harvest the seed-heads and green herbage at the top of the plant; thus, avoiding residual vegetation in the lower portions of the plant. Given the more selective nature of sheep, sheep are more likely to exhibit this behavior. It is commonly accepted that Lehmann lovegrass is unpalatable during the growing season when growing in pastures with other perennial grasses (Bridges 1941, Ruyle and Cox 1985); yet, Reese (1980) showed percent use of Lehmann lovegrass during the summer months was greater than use of native perennial grasses (Bouteloua eriopida). This inconsistency suggests animal preference for Lehmann lovegrass does vary. Furthermore, production of Lehmann lovegrass seed under favorable conditions can approach $448 \mathrm{~kg} \mathrm{ha}^{-1}$ (Anderson and Hafenrichter 1963), or six billion seeds $\mathrm{ha}^{-1}$. Under these conditions, even occasional use of Lehmann lovegrass may lead to significant seed consumption.

Once selected, prehension and mastication of the seed and associated plant parts are the first processes that can damage the seed and its viability. Disarticulation of seed during prehension represents a reduction of potential seed intake. This aspect has not been examined but is likely to depend heavily upon plant phenology and mode of prehension. The proportion of seeds damaged by mastication is likely to be quite variable since ruminant chewing behavior during eating is erratic, lacking repetitive hehavior (Beauchemin 1991). Factors affecting seed damage in our study likely include stress due to close human interaction (Le Neindre et al. 1993), stress due to confinement (Baldock and Sibley 1990, Lynch et al. 1992), and effects of ruminal distension on eating rate (Baumont et al. 1990). Because conditions imposed by the study probably altered eating rate and chewing behavior, the effect of chewing on seed damage under free-ranging conditions cannot be directly determined based upon these data. However, our data indicate that considerable Lehmann lovegrass seed can bypass the buccal cavity undamaged. Seed damage due to mastication by beef cattle is likely to be much less than damage by sheep. For example, processing of cereal grains, especially corn and sorghum, improves their digestibility for cattle considerably, yet processing is unnecessary when feeding grains to sheep (Hale 1973). Sheep do not require processing of feed grains because they chew their meals more thoroughly than cattle (Owens and Goetsch 1988).

Within a given diet, seed size, density and shape are primary determinants of the time a seed is exposed to ruminal digestion and rumination (Kaske and Engelhardt 1990, Sutherland 1988). Research examining these attributes on ruminal particulate dynamics is largely restricted to forage leaf and stem fractions, with few studies comparing a range of particle densities representative of seeds commonly encountered by the grazing animal. The seed of Lehmann lovegrass is spheroidal to cylindrical measuring $0.6 \times 0.4 \mathrm{~mm}$ (Sumrall et al. 1991). When dry, seed density is 3.0 $\mathrm{g} \mathrm{ml}^{-1}$ and approaches $2.6 \mathrm{~g} \mathrm{ml}^{-1}$ when hydrated (Unpublished data. Fredrickson et al.). Density of forage particles in the rumen range from less than $1 \mathrm{~g} \mathrm{~m}^{-1}$ (Van Soest 1975) to $1.4 \mathrm{~g} \mathrm{ml}^{-1}$ (Hooper and Welch 1985). Based upon studies examining ruminal passage of forage particles, Lehmann lovegrass seed should have a short residence time in the mast (Sutherland 1988, Katoh et al. 1988), and a high probability of exiting the rumen via the reticulo-omasal orifice (Kaske and Engelhardt 1990) without being impeded from exiting the rumen by the omasum (Poppi et al. 1980). The short residence time in the rumen lessens the prob- ability of seed damage by rumination and ruminal digestive processes. Size and density attributes of I ehmann lovegrass seeds also suggest rapid movement through the postruminal intestinal tract. This view is supported by studies examining postruminal passage rates in steers (Siciliano-Jones and Murphy 1986).

Simao Neto et al. (1987) studied seed passage of signal grass (Brachchiaria decumbens; $1.1 \mathrm{~g} \mathrm{ml}^{-1}, 2 \mathrm{~mm} \times 4.7 \mathrm{~mm}$ ) and carpet grass (Axonopus affinis; $1.6 \mathrm{~g} \mathrm{ml}^{-1}$ ) through the digestive tract of livestock. Recovery of undamaged seeds fed to sheep was 0.7 and $6.6 \%$ for signal and carpet grass, respectively, while recovery of seed fed to cattle was 22 and $37 \%$, respectively. Mean retention time in the digestive tract did not differ between livestock species, with mean retention times of approximately 60 and 55 hours for signal and carpet grass, respectively. Siman Neto et al. (1987) also suggest that sheep provide a considerably more conservative estimate of the influence of ruminant digestion on seed viability. From data in Experiment 1 and 3 (combined effect of mastication plus ruminal and intestinal digestion), we estimated total recovery of germinable seed to be approximately $13.1 \%$ (SE $=3.9$ ). Also, $48 \%(\mathrm{SE}=6)$ of the germinable seed was recovered within 24 hours, suggesting mean retention time approached 24 hours. Size, density, and shape of Lehmann lovegrass seed may explain, at least in part, the reduced mean retention time and greater recovery of viable seed than observed by Simao Neto et al. (1987). Other aspects of animal physiology and diet also should be considered. For example, Jones and Simao Neto (1987) determined that although the proportion of seed in the diet did not affect seed recovery, quality of the diet did. Ten percent of the seed was recovered when sheep were fed a low quality diet, and $28 \%$ was recovered when fed medium or high quality diets. This agrees with reports that digestive passage rates increase with diet quality (Galyean and Owens 1991) and recovery of viable seeds are greater when resident time in the digestive tract is least (Ocumpaugh et al. 1995).

Based upon in sacco data obtained in Experiment 3, it appears that Lehmann lovegrass seed is resistant to ruminal digestion with $16 \%$ disappearance at 120 hours. In contrast, in sacco dry matter disappearance for a low quality mature forage is $39 \%(5.9 \%$ crude protein, King et al. 1995), and $29 \%$ for disappearance of whole corn incubated in sheep on a roughage diet (Flachowsky et al. 1992). This indicates that whole seeds from graminoids are resistant to ruminal digestion and that Lehmann lovegrass seed is more resistant than corn. Ruminal incubation does affect 21 day germination, but this effect is minimal until 72 hours. At 120 hours of incubation, few seeds germinated. That seeds incubated in vitro for 48 and 72 hours had a greater percent of dormant seeds than seeds not incubated indicates a shift toward increased dormancy with longer in vitro incubation periods which may have important consequences affecting seedbed ecology and establishment of Lehmann lovegrass.

In vitro techniques described by Ocumpaugh and Swakon (1993) appear to be a good indicator of the effects of ruminal digestion on seed viability if dormant (seeds not germinating but viable) and germinable seeds are considered for both the 48 and 72 hour incubation times. Because of obvious bias due to partial seed recovery and difficulty recovering nongerminable seed from feces, a comparison between in vitro and in situ total tract influences on germination was not made. However, gastric digestion may influence seed physiology and may affect interpretation of digestion effects on seed viability. A combination of ruminal in sacco and postruminal mobile nylon bag techniques (Vanhatalo 
and Ketoja 1995) may provide a better test of the accuracy of in vitro techniques to predict the effect of total tract digestion on seed germination.

Because it is not known if Lehmann lovegrass seeds will germinate and establish in arid environments after passing through the digestive tract of sheep, we cannot conclude that sheep contribute to the expansion of Lehmann lovegrass populations. Lehmann lovegrass seeds are excreted in a nutrient-rich environment. Furthermore, Lehmann lovegrass seeds germinate better with light exposure and large temperature fluctuations (Roundy et al. 1992), although temperature fluctuations may be greater for seeds in feces the amount of light affecting the seeds will be reduced. This may maintain dormancy and cause a sustained release of viable seed that will be exposed to a variety of conditions, including conditions favorable for Lehmann lovegrass establishment or continued dispersal via phase II mechanisms described by Chambers and MacMahon (1994). Seeds from other grasses remain viable after being buried in feces for periods greater than 30 months (Wicklow and Zak 1983).

\section{Conclusions}

The rapid expansion of Lehmann lovegrass from seeded areas into adjoining native rangelands is thought to be due to seed dispersal by wind and water. The possible influence of ruminants and other seed predators on the expansion of Lehmann lovegrass in North America has received little attention. This study confirms Lehmann lovegrass seeds can pass through the ruminant digestive tract and remain viable. If seeds germinate and establish in dung, or after decay of dung, then ruminants must be considered as a factor that facilitates the spread of Lehmann lovegrass. In this case, knowledge of gastrointestinal passage rates and effects of digestion on seed viability will be helpful in developing management strategies that seek to reduce the rate of lovegrass spread.

\section{Literature Cited}

Abu-Zanat, M.M.W. 1989. Ingestive behavior of cattle grazing in lightly- and heavily-grazed patches of Lehmann lovegrass (Eragrostis lehmanniana Nees). Ph. D. Dissertation, Univ. Arizona, Tucson, Ariz.

Anable, M.E., M.P. McClaren, and G.B. Ruyle. 1992. Spread of introduced Lehmann lovegrass Eragrostis lehmanniana Nees. in Southern Arizona, USA. Biol. Conserv. 61:181-188.

Anderson, D. and A.L. Hafenrichter. 1963. Lehmann lovegrass comes of age-proves value on range. Arizona Farmer-Ranchman. 1(6):38-39.

AOAC. 1990. Official methods of analyses (15th ed.), Assoc. Official Anal. Chem., Washington, D.C.

AOSA. 1970. Tetrazolium testing handbook. Contribution No. 29 to the handbook on seed testing. D.F. Grabe (Ed.). Assoc. Official Seed Anal., Lincoln, Neb.

Baldock, N.M. and R.M. Sibly. 1990. Effects of handling and transportation on the heart rate and behaviour of sheep. Appl. Anim. Behav. 28:15-39.

Baumont, R., C.H. Malbert, and Y. Ruckebusch. 1990. Mechanical stimulation of rumen fill and alimentary behaviour in sheep. Anim. Prod. 50:123-128.

Beauchemin, K.A. 1991. Ingestion and mastication by dairy cattle. Food Anim. Prac. 7:430-463.

Bridges, J.O. 1941. Reseeding trials on arid range land. New Mexico Agr. Exp. Sta. Bull. 278. Las Cruces, N.M.
Chambers, J.C. and J.A. MacMahon. 1994. A day in the life of a seed: movements and fates of seeds and their implication for natural and managed systems. Annu. Rev. Ecol. Syst. 25:263-292.

Cox, J.R., M.H. Martin-R, F.A. Ibarra-F, J.H. Fourie, N.F. G. Rethman, and D.G. Wilcox. 1988. The influence of climate and soils on the distribution of four African grasses. J. Range Manage. 41:127-139.

Cox, J.R. and G.B. Ruyle. 1986. Influence of climatic and edaphic factors on the distribution of Eragrostis lehmanniana Nees. in Arizona, USA. J. Grassl. Soc. So. Afr. 3:25-29.

Flachowsky, G., P. Baldeweg, and Gr. Schein. 1992. A note on the in sacco dry matter degradability of variously processed maize grains and of different maize varieties in sheep. Anim. Feed Sci. Tech. 39:173-181.

Galyean, M.L. and F.N. Owens. 1991. Effects of diet composition and level of feed intake on site and extent of digestion in ruminants. $p$. 483-514. In: T. Tsuda, Y. Sasaki, and R. Kawashhima (Eds.), Physiological aspects of digestion and metabolism in ruminants, Academic Press, Inc., N.Y.

Hale, W.H. 1973. Influence of processing on the utilization of grains (starch) by ruminants. J. Anim. Sci. 37:1075-1080.

Holzworth, L.K. 1980. Registration of 'Cochise' Atherstone lovegrass. Crop Sci. 20:823-824.

Hooper, A.P. and J.G. Welch. 1985. Effects of particle size and forage composition on functional specific gravity. J. Dairy Sci. 68:1181-1188.

Janzen, D.H. 1984. Dispersal of small seeds by big herbivores: foliage is the fruit. Amer. Nat. 123:338-353.

Jones, R.M. and M. Simao Neto. 1987. Recovery of pasture seed ingested by ruminants. 3 . The effects of the amount of seed in the diet and of diet quality on seed recovery from sheep. Aust. J. Exp. Agr. 27:253-256.

Kaske, M. and W.V. Engelhardt. 1990. The effect of size and density on mean retention time of particle in the gastrointestinal tract of sheep. Brit. J. Nutr. 63:457-465.

Katoh, K. , F. Sato, A. Yamazaki, Y. Sasaki, and T. Tsuda. 1988. Passage of indigestible particles of various specific gravities in sheep and goats. Brit. J. Nutr. 60:683-687.

King, D.W., R.E. Estell, E.L. Fredrickson, K.M. Havstad, J.D. Wallace, and L.W. Murray. 1995. Effects of (Flourensia cernua) ingestion on intake, digesta kinetics, in situ digestion, and ruminal fermentation of sheep consuming tobosa. J. Range Manage 49:331-335.

Le Neindre, P., P. Poindron, G. Trillat, and P. Orgeur. 1993. Influence of sheep breed on reactivity of sheep to humans. Genet. Select. Evol. 25:447-458.

Lynch, J.J., G.N. Hinch, and D.B. Adams. 1992. The behaviour of sheep. C. A. B. Intern., Wallingford, UK.

Mertens, D.R. and J.R. Loften. 1980. The effect of starch on forage fiber digestion kinetics in vitro. J. Dairy Sci. 63:1437-1444.

Moody, M.E. and R.N. Mack. 1988. Controlling the spread of plant invasions: the importance of nascent foci. J. Appl. Ecol. 25:1009-1021.

Ocumpaugh, W.R. and D.H.D. Swakon. 1993. Simulating grass seed passage through the digestive system of cattle: A laboratory technique. Crop Sci. 33:1084-1090.

Ocumpaugh, W.R., C.R. Tischler, and L.S. Valle. 1995. Post-harvest seed dormancy effects on Kleingrass germination following simulated digestion by cattle. Crop Sci. 35:260-263.

Owens, F.N. and A.L. Goetsch. 1988. Ruminal fermentation. In: D.C. Church (Ed.), The ruminant animal, Prentice Hall, Englewood Cliffs, N.J. pp. 145-171.

Poppi, D.P., B.W. Norton, D.J. Minson, and R.E. Hendricksen. 1980. The validity of critical size theory for particles leaving the rumen. $J$. Agric. Sci. 94:275-280.

Reese, M.E. 1980. Seasonal utilization of Lehmann lovegrass and black grama in the desert grassland. M. S. Thesis, Univ. Arizona, Tucson, Ariz.

Roundy, B.A., R.B. Taylorson, and L.B. Sumrall. 1992. Germination responses of Lehmann lovegrass to light. J. Range Manage. 45:81-84. 
Ruyle, G. and J. Cox. 1985. Lehmann lovegrass a naturalized citizen. Arizona Farmer-Stockman 64:26.

SAS. 1989. SAS User's Guide: Statistics, ver. 6.07. SAS Institute, Inc. Cary, N.C.

Siciliano-Jones, J. and M.R. Murphy. 1986. Passage of inert particles varying in length and specific gravity through the postruminal digestive tract of steers. J. Dairy Sci. 69:2304-2311.

Simao Neto, M., R.M. Jones, and D. Ratcliff. 1987. Recovery of pasture seed ingested by ruminants. 1 . Seed of six tropical pasture species fed to cattle, sheep and goats. Aust. J. Exp. Agr. 27:239-246.

Sumrall, L.B., B.A. Koundy, and V.K. Winkel. 1991. Influences of canopy removal by burning and clipping on emergence of Eragrostis lehmanniana seedlings. J. Wildl. Fire. 1:34-40.
Sutherland, T.M. 1988. Particle separation in the forestomachs of sheep.p. 43-73. In: A. Dobson and M. J. Dobson (Eds.), Aspects of digestive plysiology in ruminants, Comell Univ. Press, Ithica, N.Y.

Tilley, J.M.A. and R.A. Terry. 1963. A two-stage technique for the in vitro digestion of forage crops. J. Br. Grassl. Soc. 18:104-111.

Vanhatalo, A. and E. Ketoja. 1995. The role of the large intestine in post-ruminal digestion of feeds as measured by the mobile-bag method in cattle. Br. J. Nutr. 73:491-505.

Van Soest, P.J. 1975. Physio-chemical aspects of fibre digestion. $p$. 351-365. In: I. W. McDonald and A. C. I. Warner (Eds.), Digestion and metabolism in the ruminant, Univ. New England Publ., Armidale, Australia.

Wicklow, D.T. and J.C. Zak. 1983. Viable grass seeds in herbivore dung from a semi arid grassland. Grass Forage Sci. 38:247-249. 